\title{
Antioxidant Activity, Total Phenol and Total Flavonoid Contents of Trachystemon orientalis (L.) G. Don
}

\author{
Ozlem Sacan \\ Department of Chemistry, Faculty of Engineering, Istanbul University-Cerrahpasa, Istanbul, Turkey
}

ORCID IDs of the authors: O.S. 0000-0001-6503-4613.

Please cite this article as: Sacan O. Antioxidant Activity, Total Phenol and Total Flavonoid Contents of Trachystemon orientalis (L.) G. Don. Eur J Biol 2018; 77(2): 70-75.

ABSTRACT

Objective: For many years, plants have been considered a source of alternative medicine and are used for the treatment of several diseases. These medicinal plants are excellent sources of phytochemicals and antioxidant activity. Trachystemon orientalis (L.) G. Don (Boraginaceae) originates from East Bulgaria but can be found mostly in West Caucasia and the Black Sea region of Turkey. Its flowering branches, rhizomes, and leaves are used as food.

Materials and Methods: The antioxidant activity of a T. orientalis aqueous infusion was investigated using various antioxidant tests, such as reducing power and radical scavenging activity. The phenolic and flavonoid contents were also determined. Results were compared with natural and synthetic antioxidants.

Results: The results demonstrated that $T$. orientalis (L.) is a good source of antioxidants.

Conclusion: This study suggested that $T$. orientalis extract can be considered a useful natural antioxidant source because of its flavonoid, phenolic, and anthocyanin contents. The food and cosmetic industries might employ T. orientalis extract as an alternative additive to other highly toxic synthetic antioxidants.

Keywords: Antioxidant activity, oxidative stress, phenolic compounds, reducing power, radical scavenging activity, flavonoid, Trachystemon orientalis (L.) G. Don.

\section{INTRODUCTION}

Oxidative stress is defined as the disturbance or lack of balance in the production of free radicals and the antioxidant system $(1,2)$. Disturbances in this normal redox status can cause toxic impacts by producing peroxides and free radicals that damage cell and tissue components such as lipids, proteins and DNA $(3,4)$. In humans, oxidative stress causes many diseases such as tissue injury, cell death, cancer, cardiovascular diseases, arteriosclerosis, neural disorders, Parkinson's disease, Alzheimer's disease, ageing, skin irritations and inflammations, diabetes mellitus and chronic fatigue syndrome (5-8). Antioxidants are known to delay or inhibit the oxidation of substrates even when present in low concentrations (9). Synthetic antioxidants such as propyl gallate (PG), butylated hydroxylanisole (BHA), butylated hydroxyltoluene (BHT), and tertiary butyl hydroquinone (TBHQ) protect lipids found in foods from the harmful effect of oxidation. However, both BHT and $\mathrm{BHA}$ are restricted from use because of their toxic and carcinogenic effects (10). Because of the negative effect of synthetic compounds, natural antioxidants rather than synthetic antioxidants are much more preferred by consumers. Thus, the demand for natural and safer antioxidants is growing.

Studies have shown that higher plants are excellent sources of functional compounds such as anthocyanins, vitamins, flavonoids, dietary glutathione and carotenoids

This study was presented at the "XX. National Chemistry Congress”, “2006”, “Kayseri, Turkey”. 
- which are responsible for antioxidants' function. Therefore, they are considered as important nutraceuticals with many health benefits $(11,12)$. T. orientalis is a plant of East Bulgarian origin. In Turkey, it is popularly known as Galdirek, Kaldirik, Hodan, Kalduruk (Bolu), Tamara (Trabzon), Burgi (Artvin) and Zilbit, Ispit (Zonguldak). The plant is chiefly found in the West Caucasia and Black Sea regions and is consumed as a vegetable in Istanbul and other regions of the Black Sea $(13,14)$. A concoction of their fresh roots is used like a tonic on the skin against rheumatism and/or for the healing of inflamed wounds (15). Additionally, it has diuretic effects and can be used as a blood purifier (16). T. orientalis is reported to contain nitrate salts, tannins, mucilage, essential oils, resin and saponins (17).

A quantitative assessment of total phenols, flavonoids and anthocyanine contents of $T$. orientalis was carried out in this study. In addition, the reducing power of the aqueous infusion extract, ferric thiocyanate antioxidant activity and The 1,1-Diphenyl-2-picrylhydrazyl (DPPH) radical scavenging activity of the plant was conducted.

\section{MATERIALS AND METHODS}

\section{Plant Materials}

The leaves of $T$. orientalis were acquired from Istanbul, Turkey in the month of March 2017. The fresh sections were cleaned with water and dried at $20^{\circ} \mathrm{C}$, then stored at $-20^{\circ} \mathrm{C}$ until use.

\section{Preparation of Infusion Extract}

Plant extract was prepared as a $10 \%(\mathrm{w} / \mathrm{v})$ aqueous infusion. A dried sample $(20 \mathrm{~g})$ was extracted with boiling water $(100 \mathrm{~mL})$ for 15 min while stirring.

\section{Phytochemical Tests}

The infusion extract was subjected to preliminary qualitative phytochemical analysis for the detection of major chemical groups (Table 1). The details are below:

1. Phenols were analysed after the aqueous solution of $T$. orientalis infusion was filtered using filter paper. A drop of molybdophosphoric acid reagent was added to the sediment and absorbed into $\mathrm{NH}_{3}$ vapour.

2. Braemer's test for tannins was adopted for tannins determination. A $10 \%$ alcoholic $\mathrm{FeCl}_{3}$ solution was added to $2-3 \mathrm{~mL}$ of infusion extract.

3. Steroids and terpenoids were determined using the Liebermann-Burchardt test. Into one $\mathrm{mL}$ of infusion extract solution, one $\mathrm{mL}$ of $\mathrm{CHCl}_{3}$, two / three $\mathrm{mL}$ acetic anhydride and one to two drops of $98 \% \mathrm{H}_{2} \mathrm{SO}_{4}$ were added.

4. Dragendorff's reagent was added to $1 \mathrm{~mL}$ of infusion extract for alkaloid determination.

5. Bornträger's test for anthraquionones was carried out by heating approximately $50 \mathrm{mg}$ of the infusion extract with $10 \%$ $\mathrm{FeCl}_{3}$ solution and one $\mathrm{mL}$ of $37 \% \mathrm{HCl}$. Diethyl ether was used to rinse the cooled extract after filtration, before further extraction with concentrated $\mathrm{NH}_{3}$.

\section{Determination of Antioxidant Activity of the Extract}

\section{Determination of Total Phenolic Compounds}

Total phenolic compounds of $T$. orientalis were determined with the Folin-Ciocalteu reagent using Slinkard and Singleton's method (1977), pyrocatechol was used as a standard for phenolic compound (18). Absorbance was measured spectrophotometrically at $760 \mathrm{~nm}$.

\section{Determination of Total Flavonoid Content}

Total content of flavonoids in T. orientalis was determined spectrophotometrically at $510 \mathrm{~nm}$ (19). The results are presented as the mean $( \pm \mathrm{SD}) \mathrm{mg}$ of $(+)$-catechin equivalents per gram of extract.

\section{Determination of the Anthocyanin Content}

The anthocyanin composition of T. orientalis was estimated by the modified method of Padmavati et al. (20). The anthocyanin concentration was determined spectrophotometrically at 530 and $657 \mathrm{~nm}$. The absorbance of anthocyanin was calculated using the extinction coefficient of $31.6 \mathrm{M}^{-1} \mathrm{~cm}^{-1}$.

\section{Ferric Thiocyanate (FTC) Antioxidant Activity}

Osawa and Namiki's method was employed for the determination of FTC activity (21). The measurement of absorbance was made spectrophotometrically at $500 \mathrm{~nm}$. a-Tocopherol was used as positive control. All tests were conducted in triplicate and the average was calculated.

FTC antioxidant activity was calculated with the following equation:

Inhibition $(\%)=[(\mathrm{A}-\mathrm{B}) / \mathrm{A}] \times 100$

A represents the control and $B$ is the sample.

\section{Reducing Power}

The reducing potential of $T$. orientalis was analysed using Oyaizu's method (22). Absorbance was measured spectrophotometrically at $700 \mathrm{~nm}$, high absorbance values indicate a strong reducing power.

\section{DPPH Radical Scavenging Potential}

DPPH radical scavenging activity of antioxidants developed by Brand-Williams et al. (23) was adopted in this study. The equation below was used for the calculation of the DPPH radical activity.

DPPH radical scavenging activity $(\%)=\left(A_{0}-A_{1} / A_{0}\right) \times 100$

$A_{0}$ indicates the absorbance of the control and $A_{1}$ indicates the absorbance of the sample.

\section{RESULTS}

In this study, the presence of tannins, phenols, and anthraquinones was detected in the $T$. orientalis aqueous infusion extract (Table 1).

The level of total phenolic compounds of $T$. orientalis is presented in Table 2. An equivalent of $36 \mu \mathrm{g}$ of pyrocatechol was obtained in $1 \mathrm{mg} / \mathrm{mL}$ of aqueous infusion extract. The concen- 
tration of flavonoids in $1 \mathrm{mg}$ of the $T$. orientalis aqueous infusion extract was found to be $29.34 \pm 0.62 \mu \mathrm{g}$ catechin equivalents. This suggests that the antioxidant activities of $T$. orientalis might be due to its high level of flavonoid content. As indicated in Table 2, the anthocyanin level of $T$. orientalis in this study was $0.35 \pm 0.06 \mu \mathrm{mol} / \mathrm{g}$ extract.

These primary products (i.e. peroxides) can be measured by the ferric thiocyanate method in the linoleic acid system, with

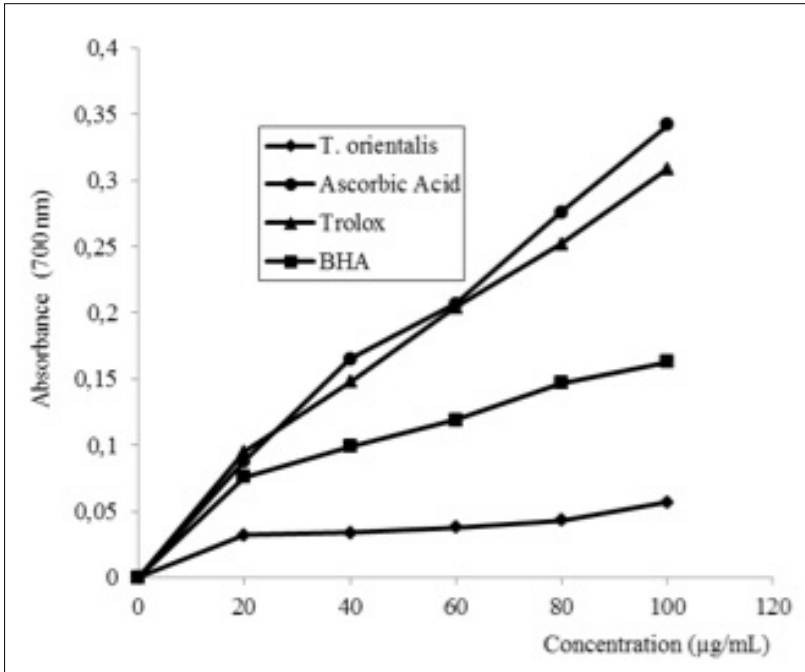

Figure 1. Reducing power of T. orientalis (L.) G. Don. aqueous infusion extract. a-tocopherol employed as standard. As a result, high peroxide formation during the emulsion incubation causes a high absorbance value. The effects of varied concentrations ( 20 and $60 \mu \mathrm{g} /$ $\mathrm{mL}$ ) of $T$. orientalis of linoleic acid emulsion on lipid peroxidation are given in Table 3. At forty-eight hours of testing, the percentage peroxidation inhibition of 20 and $60 \mu \mathrm{g} / \mathrm{mL}$ of aqueous infusion extracts on the linoleic acid system was $64.57 \pm 3.53 \%$ and $75.48 \pm 0.62 \%$ respectively. These values were higher than that of $100 \mu \mathrm{g} / \mathrm{mL}$ a-tocopherol $(61.19 \pm 0.61 \%)$.

More so, a high absorbance value in reducing power test signifies a strong reducing power. The reducing power of $T$. orientalis increased the with increasing concentration of the extract (Figure 1). However, it's reducing effect was weak when compared

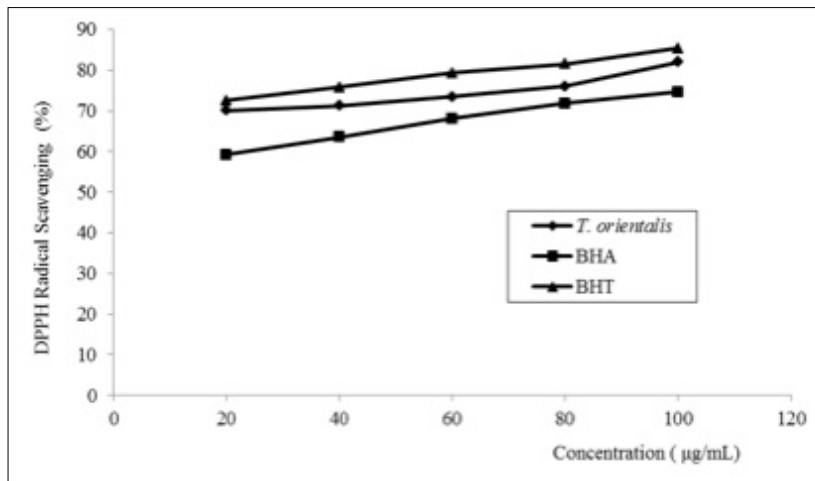

Figure 2. DPPH radical scavenging activity of aqueous extracts of T. orientalis (L.) G. Don.

Table 1. Preliminary phytochemical screening of aqueous infusion extract of T. orientalis (L.) G. Don

\begin{tabular}{|c|c|c|}
\hline Tested for & Detection* & Test performed \\
\hline Phenols & ++ & Phosphomolybdic acid test \\
\hline Tannins & +++ & Braemer's test \\
\hline Steroids and Terpenoids & --- & Liebermann- Burchardt test \\
\hline Alkaloids & --- & Dragendorff's test \\
\hline Anthraquinones & +++ & Bornträger test \\
\hline
\end{tabular}

Table 2. Total phenolic compounds (as pyrocatechol equivalent), total flavonoids (as catechin equivalent) and total anthocyanin of T. orientalis (L.) G. Don. aqueous infusion extract

\begin{tabular}{lccc}
\hline Concentration $(\boldsymbol{\mu g} / \mathbf{m L})$ & $\begin{array}{c}\text { Phenolic Compounds } \\
(\boldsymbol{\mu g} \text { pyrocatechol/mg extract) }\end{array}$ & $\begin{array}{c}\text { Flavonoids } \\
\boldsymbol{\mu g} \text { catechin/mg extract) }\end{array}$ & $\begin{array}{c}\text { Anthocyanins } \\
(\boldsymbol{\mu m o l} / \mathbf{g} \text { extract) }\end{array}$ \\
\hline 250 & $29.36 \pm 0.87$ & $7.94 \pm 0.31$ & $0.35 \pm 0.06$ \\
\hline 500 & $32.00 \pm 0.32$ & $13.92 \pm 0.24$ & - \\
\hline 750 & $34.17 \pm 1.10$ & $21.86 \pm 0.74$ & - \\
\hline 1000 & $36.00 \pm 0.59$ & $29.34 \pm 0.62$ & - \\
\hline
\end{tabular}

Values: Mean \pm SD $(n=3)$. 
Table 3. Antioxidant activity (FTC) of aqueous infusion extracts of $T$. orientalis (L.) G. Don in comparison to a-tocopherol as reference antioxidant at 48 hours

\begin{tabular}{lc}
\hline Compounds & (Inhibition \%) \\
\hline T. orientalis $(20 \mu \mathrm{g} / \mathrm{mL})$ & $64.57 \pm 3.53$ \\
\hline T. orientalis $(60 \mu \mathrm{g} / \mathrm{mL})$ & $75.48 \pm 0.62$ \\
\hline a-Tocopherol $(100 \mu \mathrm{g} / \mathrm{mL})$ & $61.19 \pm 0.61$ \\
\hline Values: Mean \pm SD $(\mathrm{n}=3) . \mathrm{FTC}:$ Ferric Thiocyanate & \\
\hline
\end{tabular}

to the reducing power of positive controls like BHA, Trolox and ascorbic acid.

The DPPH assay is a highly effective and easy to apply spectrophotometric method for understanding the effect of radical compounds, as well as radical scavenging capacities of antioxidants. Figure 2 represents the DPPH radical scavenging activity of $T$. orientalis extract, and that of $\mathrm{BHA}$ and $\mathrm{BHT}$ as positive control. Both the extract and the standards exhibited scavenging properties according to $\mathrm{BHT}, \mathrm{T}$. orientalis and $\mathrm{BHA}$ had the following activities respectively $85.45 \pm 9.78 \%>81.99 \pm 7.45 \%>$ $74.61 \pm 9.04 \%$.

\section{DISCUSSION}

Reactive oxygen species and reactive nitrogen species are highly reactive oxidizing molecules which are constantly generated during normal cellular activities. For instance, the activity of the mitochondrial respiratory chain and inflammation could generate these compounds, which could lead to damage of other biological molecules such as proteins and DNA. In the last decade, there has been a growing interest in natural antioxidants. Studies shows that diets rich in fruits, vegetables and derived products have been defined to alleviate chronic diseases. These food containing herbs are rich in phytochemical molecules such as vitamins, phenolic antioxidants etc, thus aids normal health and wellbeing (24-27).

Polyphenols are a diverse group of plant secondary metabolites, encompassing subgroups such as tannins and flavonoids among others. They are found throughout the plant kingdom, with their biological function lying mostly within their defensive capabilities against herbivores, pathogens, and UV-B radiation. Tannins are structurally the most complex group of polyphenols, they are large ringed, present in several plant families and are reported to exhibit anticancer or cancer preventive activity and antioxidant capability (28-29). Therefore, T. orientalis aqueous infusion extract which is a good source of tannins may possess significant anticancer activity and antioxidant potentials. In recent years, several clinical trials,-as well as other evidences have indicate that diseases precipitated by oxidative stress can be prevented or managed with high flavonoids rich foods (30-32). Previous studies by Özen (33) report a phenolic content of $82.1 \pm 1.5 \mathrm{mg}$ pyrocatechol/g dry weight of $T$. orientalis. Moreover, Ayvaz (34) reported a phenol concentration of
$68.9 \mathrm{mg}$ pyrogallat/g and $17.5 \mathrm{mg}$ pyrogallat/g respectively in water and ethanolic extracts. Conversely, the phenolic content of $T$. orientalis in this study (at $500 \mu \mathrm{g} / \mathrm{mL}$ aqueous infusion extract concentration) was below those of the aqueous infusion extracts in earlier reports $(32.00 \pm 0.32 \mathrm{mg}$ pyrocatechol $/ \mathrm{mg})$. The difference in concentration may be attributed to the concentration of extract used for the qualitative analysis as well as the extraction methods employed.

In many herbs, antioxidant activities correlate positively with phenolic contents (35). Several works of literatures have reported the key role of phenolic compounds in scavenging free radicals, as well as the high scavenging ability of phenol rich plant samples (36-39).

Flavonoids in plants are involved in providing pigmentation for flowers, fruits and seeds to attract pollinators and seed dispersers, improving fertility, aiding germination of pollen, protecting against stress, and acting as signal molecules in plant microbe interactions. Flavonoids are greater antioxidants than natural phenolic compounds (40). Moreover, the antioxidant activity of plant products is also correlated to their total flavonoid content. Thus, it is suggested that the consumption of flavonoid-containing nourishments is beneficial for protection from free radical damage. The flavonoids content quantified from $T$. orientalis in this study at $1000 \mu \mathrm{g} / \mathrm{mL}$ aqueous infusion extract (29.34 $\pm 0.62 \mu \mathrm{g}$ catechin $/ \mathrm{mg}$ extract) was comparable to that of ethanol extract ( $29.4 \mathrm{mg}$ catechin $/ \mathrm{g}$ extract), but lower that of aqueous extract (56.88 $\mathrm{mg}$ catechin /g extract respectively) reported by Ayvaz (33).

Anthocyanins which are a type of antioxidant flavonoids have diverse functions in higher plants. They act as insect and/or animal attractors thanks to the coloration they confer to plants. It is also suggested that they have a protective effect against UV light, infection by pathogens as well as scavenging reactive oxygen species. Furthermore, they confer drought, low temperature and high salinity resistance in plants. In general, anthocyanins find their way into human diet through vegetables, fruit, tea, beans, coffee, cereals, herbs and spice extract. They are famous for their pharmacological effects such as antioxidant, antitumor, anti-inflammatory and antimutagenic activities (41). Comparatively, the anthocyanin content of $T$. orientalis in this study was extremely low $(0.35 \pm 0.06 \mu \mathrm{mol} / \mathrm{g}$ extract $)$, in relation to the $15.2 \pm 0.1 \mathrm{mg}$ cyanidin 3-glucoside/g dry weight reported by Özen (34).

Lipid peroxidation mediated chain reactions are processes initiated by free radicals that result in the production of peroxide implicated in several biological complications (42). The mechanism for spectrophotometric estimation of lipid hydroperoxidation involves the oxidation of ferrous ion to ferric ion, followed by coupling to thiocyanate to produce a complex. By this, the amount of peroxide produced during the initial stages of oxidation (the primary product of lipid oxidation) is quantified. The findings of this study suggest that $T$. orientalis aqueous infusion extract has a high peroxidation inhibition capacity at 20 and 60 
$\mu \mathrm{g} / \mathrm{mL}$ as compared to a-tocopherol and therefore, may serve as an alternative source of antiperoxidants.

Reducing power is related to antioxidant activity due to the fact that antioxidant can give off their electrons for the reduction of reactive radicals. Thus, reducing power can be used to give information about antioxidative potentials of prospective antioxidants (43). It can be measured by the direct reduction of Fe $\left[(\mathrm{CN})_{6}\right]_{3}$ to $\mathrm{Fe}\left[(\mathrm{CN})_{6}\right]_{2}$, forming intense Perl's Prussian blue complex measured at $700 \mathrm{~nm}$. An increase in absorbance indicates an increase in reducing capacity as a result of an increase in the formation of the complex (44). The T. orientalis aqueous extract in comparison, had a reducing power value $(0.05$ at $60 \mu \mathrm{g} / \mathrm{mL})$ less than the 0.2 previously reported by Özen (34). This difference may be attributed to the variation in antioxidant phytochemical level between the sample used, arising from growth conditions and environmental effects on the plants.

A common method for determining antioxidant capability is the DPPH radical scavenging reaction. A reverse in formation of DPPH radicalisation occurs when antioxidants are added to radicals, thus decolourisation occurs. The potential of plant extracts to act as antioxidants depends on the redox properties and electron delocalization of phenolic hydroxyl groups of their constituent polyphenolic compounds. In this study, T. orientalis aqueous infusion extract was found to contain a moderate amount of phenolic compounds, and an above average DPPH radical scavenging activity (81.99\%). A previous study (34) reported an approximate $50 \%$ inhibition at $100 \mu \mathrm{g} / \mathrm{ml}$ of extract. Also, Ayvaz (33) reported an $\mathrm{IC}_{50}$ DPPH radical scavenging potential of aqueous extract of $0.41 \mathrm{mg} / \mathrm{mL}$ and $2.6 \mathrm{mg} / \mathrm{mL}$ of the ethanolic extract. The DPPH radical scavenging capability of aqueous $T$. orientalis extract can be attributed to its ease in abstracting a hydrogen atom from the hydroxyl group of its phenolic constituents.

\section{CONCLUSION}

This study suggests that $T$. orientalis extract can be considered as a useful natural antioxidant source because of its flavonoids, phenolic and anthocyanin contents. Furthermore, it may serve as a cheap and readily accessible source of natural antioxidant. Therefore, the food and cosmetic industries might employ $T$. orientalis extract as an alternative additive to the more toxic synthetic antioxidants.

Peer-review: Externally peer-reviewed.

Acknowledgements: My sincere gratitude goes to Prof. Dr. Kerim ALPINAR (Faculty of Pharmacy, Istanbul University) for the identification of T. orientalis. ISTE82007.

Conflict of Interest: The author has no conflict of interest to declare.

Financial Disclosure: This work was supported by Scientific Research Project Coordination Unit of Istanbul University (Project number: 4398).

\section{REFERENCES}

1. Turko IV, Marcondes S, Murad F. Diabetes-associated nitration of tyrosine and inactivation of succinyl-CoA: 3-oxoacid CoA-transferase. Am J Physiol Heart Circ Physiol 2001; 281(6): H2289-94.

2. Maritim AC, Sanders RA, Watkins JB. Diabetes, oxidative stress, and antioxidants: A review. J Biochem Mol Toxicol 2003; 17(1): 24-38.

3. Elchuri S, Oberley TD, Qi W, Eisenstein RS, Roberts LJ, Van Remmen $\mathrm{H}$, et al. CuZnSOD deficiency leads to persistent and widespread oxidative damage and hepatocarcinogenesis later in life. Oncogene 2005; 24(3): 367-80.

4. Blomhoff R, Carlsen MH, Andersen LF, Jacobs DR. Health benefits of nuts: potential role of antioxidants. Br J Nutr 2006; 96 Suppl 2: S52-60.

5. Kalita J, Kumar V, Ranjan A, Misra UK. Role of oxidative stress in the worsening of neurologic Wilson disease following chelating therapy. Neuromolecular Med 2015; 17(4): 364-72.

6. Bakrania AK, Nakka S, Variya BC, Shah P, Patel SS. Antitumor potential of herbomineral formulation against breast cancer: Involvement of inflammation and oxidative stress. Indian J Exp Biol 2017; 55: 680-7.

7. Salles GN, dos Santos PFA, Pacheco-Soares C, Marciano FR, Hölscher C, Webste TJ, et al. A novel bioresorbable device as a controlled release system for protecting cells from oxidative stress from Alzheimer's Disease. Mol Neurobiol 2017; 54(9): 6827-38.

8. Bohnert KR, McMillan JD, Kumar A. Emerging roles of ER stress and unfolded protein response pathways in skeletal muscle health and disease. J Cell Physiol 2018; 233(1): 67-78.

9. Georgiev M, Alipieva K, Orhan I, Abrashev R, Denev P, Angelova M. Antioxidant and cholinesterases inhibitory activities of Verbascum xanthnoeniceum Griseb. and its phenylethanoid glycosides. Food Chem 2011; 128(1): 100-5.

10. Gulcin I. Antioxidant properties of resveratrol: A structure-activity insight. Innovative Food Sci Emerg Technol, 2010; 11(1): 210-8.

11. Choi CC, Kim SC, Hwang SS, Choi BK, Ahn HJ, Lee MY, et al. Antioxidant activity and free radical scavenging capacity between Korean medicinal plants and flavonoids by assay-guided comparison. Plant Sci 2002; 163(6): 1161-8.

12. Sigumura T. Food and cancer. Toxicology 2002; 181-182: 17-21.

13. Yıldırımlı Ş. Karadeniz bölgesinin bir tıbbi ve besin bitkisi Trachystemon orientalis. Ot Sistemaik Botanik Dergisi 2002; 1: 7-12.

14. Alici EH, Arabaci G. Purification of polyphenol oxidase from borage (Trachystemonorientalis L.) by using three-phase partitioning and investigation of kinetic properties. Int J Biol Macromol 2016; 93(Pt A): 1051-6.

15. Uzun E, Sariyar G, Adsersen A, Karakoc B, Ötük G, Oktayoglu E, Pirildar S. Traditional medicine in Sakarya province (Turkey) and antimicrobial activities of selected species. J Ethnopharmacol 2004; 95(2-3): 287-96.

16. Onaran A, Yilar M. Antifungal and herbicidal activity of Trachystemon orientalis (L.) G. Don against some plant pathogenic fungi and Cuscuta campestris Yunck. Iğdır Univ J Inst Sci Tech 2018; 8(1): 37-43.

17. Karagöz A, Cevahir G, Özcan T, Sadıkoğlu N, Yentür S, Kuru A. Bazı yüksek bitkilerden hazırlanan sulu ekstrelerin antiviral aktivite potansiyellerinin değerlendirilmesi. Bitkisel İlaç Hammaddeleri Toplantısı-Bildiriler, Eskişehir, 2002; 318-21. 
18. Slinkard K, Singleton VL. Total phenols analysis: automation and comparison with manual methods. Am J Enol Viticult 1977; 28: 49-55.

19. Zhishen J, Mengcheng $T$, Jianming $W$. The determination of flavonoid contents in mulberry and their scavenginfg effects on superoxide radicals. Food Chem 1999; 64: 555-9.

20. Padmavati M, Sakthivel N, Thara KV, Reddy AR. Differential sensitivity of rice pathogens to growth inhibition by flavonoids. Phytochemistry 1997; 46(3): 499-502.

21. Osawa T, Namiki M. A novel type of antioxidant isolated from leaf wax of Eucalyptus leaves. Agric Biol Chem 1981; 45(3): 735-9.

22. Oyaizu M. Studies on products of browning reaction prepared from glucose amine. Japanese J Nutr 1986; 44: 307-15.

23. Brand-Williams W, Cuvelier ME, Berset C. Use of a free radical method to evaluate antioxidant activity. LWT-Food Sci Technol 1995; 28(1): 25-30.

24. Ruxton C, Gardner E, Walker D. Can pure fruit and vegetable juices protect againts cancer and cardiovascular disease too? A review of the evidence. Int J Food Sci Nutr 2006; 57(3-4): 249-72.

25. Konczak I, Zabaras D, Dunstan M, Aguas P. Antioxidant capacity and phenolic compounds in commerciallty grown native Australian herbs and species. Food Chem 2010: 122: 260-6.

26. Krishnaiah D, Sarbatly R, Nithyanandam R. A review on the antioxidant potential of medical plant species. Food Bioprod Process 2011; 89(3): 217-33.

27. Taher MA, Tadros LK, Dawood DH. Phytochemical constituents, antioxidant activity and safety evaluation of Kei-apple fruit (Dovyalis caffra). Food Chem 2018; 265: 144-51.

28. Olajide OO, Aderogba MA, Adedapo ADA, Makinde JM. Effects of Anacardium occidentale stem bark extract on in vivo inflammatory models. J Ethnopharmacol 2004; 95: 139-42.

29. Granato D, Shahidi F, Wrolstad R, Kilmartin P, Melton LD, Hidalgo FJ, et al. Antioxidant activity, total phenolics and flavonoids contents: Should we ban in vitro screening methods? Food Chem 2018; 264 : 471-5.

30. Duthie GG, Duthie SJ, Kyle JA. Plant polyphenols in cancer and heart diseases implications as nutritional antioxidants. Nutr Res Rev 2000; 13(1): 79-106.

31. Lambert JD, Yang CS. Mechanisms of cancer preventation by tea constituents. J Nutr 2003; 133(10): 3262S-3267S.

32. Zaidun $\mathrm{NH}$, Thent $\mathrm{ZC}$, Latif AA. Combating oxidative stress disorders with citrus flavonoid: Naringenin. Life Sci 2018; 208: 111-22.
33. Ayvaz Col M. Antioxidant activity of Trachystemon orientalis (L.) G. Don (Borage) grown. and eaten as food in Ordu, Turkey. Herba Pol 2015; 61(4): 40-51.

34. Ozen T. Antioxidant activity of wild edible plants in the Black Sea Region of Turkey. Grasas Y Aceites 2010; 61(1): 86-94.

35. Hakimoglu F, Kızıl G, Kanay Z, Kızıl M, Isı H. The effect of ethanol extract of Hypericum lysimachioides on lipid profile in hypercholesterolemic rabbits and its in vitro antioxidant activity. Atherosclerosis 2007; 192(1): 113-22.

36. Sharififar F, Moshafi MH, Mansouri SH, Khodashenas M, Khoshnoodi M. In vitro evaluation of antibacterial and antioxidant activities of the essential oil and methanol extract of endemic Zataria multiflora Boiss. Food Control 2007; 18(7): 800-5.

37. Moo-Huchin VM, Moo-Huchin MI, Estrada-León RJ, Cuevas-Gloryc L, Estrada-Motaa IA, Ortiz-Vázquezc E, et al. Antioxidant compounds, antioxidant activity and phenolic content in peel from three tropical fruits from Yucatan, Mexico. Food Chem 2015; 166: 17-22.

38. Ko HC, Lee JY, Jang MG, Song MG, Song H, Kim SJ. Seasonal variations in the phenolic compounds and antioxidant activity of Sasa quelpaertensis. Ind Crop Prod 2018; 122: 506-12.

39. Alcântara MA, Polari ILB, Meireles BRLA, de Lima AEE, da Silva Junior JC, Vieira ÉA, dos Santos NA, de Magalhães Cordeiro AMT. Effect of the solvent composition on the profile of phenolic compounds extracted from chia seeds. Food Chem 2019; 275: 489-96.

40. Pietta PG. Flavonoids as antioxidants. J Nat Prod 2000; 63(7): 103542.

41. Kong JM, Chia LS, Goh NK, Chia TF, Brouillard R. Analysis and biological activities of antocyanins. Phytochemistry 2003; 64(5): 92333.

42. Perry G, Raina AK, Nunomura A, Wataya T, Sayre LM, Smith MA. How important is oxidative damage? Lessons from Alzheimer's Disease. Free Radical Bio Med 2000; 28(5): 831-4.

43. Duan X, Jiang $Y$, Su X, Zhang Z, Shi J. Antioxidant properties of anthocyanins extracted from litchi (Litchi chinenesis Sonn.) fruit pericarp tissues in relation to their role in the pericarp browning. Food Chem 2007; 101(4): 1365-71.

44. Wood LG, Gibson PG, Garg ML. A review of the methodology for assessing in vivo antioxidant capacity. J Sci Food Agric 2006; 86: 2057-66. 